\title{
Detection and differentiation of yellow head complex viruses using monoclonal antibodies
}

\author{
Chumporn Soowannayan ${ }^{1}$, Timothy W. Flegel ${ }^{1, *}$, Paisarn Sithigorngul ${ }^{2}$, Joanne Slater ${ }^{3}$, \\ Alexander Hyatt ${ }^{3}$, Sandy Cramerri ${ }^{3}$, Terry Wise ${ }^{3}$, Mark St. J. Crane ${ }^{3}$, \\ Jeff A. Cowley ${ }^{4}$, Russell J. McCulloch ${ }^{4}$, Peter J. Walker ${ }^{4}$ \\ ${ }^{1}$ National Center for Genetic Engineering and Biotechnology, and Centex Shrimp Chalermprakiat Building, \\ Faculty of Science, Mahidol University, Rama 6 Road, Bangkok 10400, Thailand \\ ${ }^{2}$ Dept. of Biology, Faculty of Science, Srinakarinwirot University, Sukhumvit Soi 23, Bangkok 10110, Thailand \\ ${ }^{3}$ CSIRO Livestock Industries, Australian Animal Health Laboratory, PO Bag 24, Geelong, Victoria 3220, Australia \\ ${ }^{4}$ CSIRO Livestock Industries, Queensland Bioscience Precinct, 306 Carmody Road, St Lucia, Queensland 4067, Australia
}

\begin{abstract}
Three monoclonal antibodies (MAbs) raised against pathogenic yellow head virus (YHV) from Thailand were tested against tissues of shrimp from Thailand, Australia, Ecuador and India that were purported to be infected with yellow head complex viruses. MAbs V-3-2B and Y-18 were specific to gp116 and gp64 envelope proteins, respectively, while Y-19 was specific to a $20 \mathrm{kDa}$ putative nucleoprotein p20. As a preliminary step, the site of reactivity of the 3 MAbs in YHV was determined by immuno-electron microscopy using ultra-thin sections of YHV-infected shrimp tissue and negatively stained, semi-purified YHV particles. As expected, MAb Y-19 reacted with viral nucleocapsids in ultra-thin sections but not with negatively stained, whole virions; MAb V-3-2B did react with negatively stained, whole virions, but not with virions or nucleocapsids in ultra-thin sections. Unexpectedly, MAb Y-18 did not react with whole or sectioned virions. By immunohistochemistry, MAbs Y-19 and Y-18 reacted with Penaeus monodon tissues infected with either YHV or with gill-associated virus (GAV) from Australia, while MAb V-3-2B reacted with YHV only. In addition, all the YHV and GAV tissue samples gave positive in situ hybridization reactions with a cDNA probe specific to the ORF1b gene of YHV. They also gave expected differential RT-PCR results for YHV and GAV. By contrast, 2 natural Thai shrimp specimens with no gross signs of disease gave similar immunohistochemical reactions and RT-PCR reactions to GAV. However, sequencing of their RT-PCR products showed that they shared $92.7 \%$ identity with GAV, but only $79.0 \%$ identity with YHV. Although specimens from Ecuador and India displayed histopathology suggestive of YHV infection, they gave negative immunohistochemical reactions with all 3 Mabs, and negative in situ hybridization results. Additional work is required to determine whether a virus from the yellow head complex was responsible for their observed histopathology. These data show that the 3 YHV MAbs could be used in diagnostic situations to differentiate some viruses in the yellow head virus complex.
\end{abstract}

KEY WORDS: Yellow head virus · YHV • Monoclonal antibody · Differential detection · Gill associated virus $\cdot$ GAV

\section{INTRODCTION}

Yellow head virus (YHV) causes acute mortality in shrimp and, thus, considerable economic loss to shrimp farmers in Thailand (Flegel 1997). It is a positive-sense, single-stranded RNA virus (genus Okavirus) in a new family (Roniviridae) of the order Nidovirales (Cowley et al. 2000, Mayo et al. 2002). It is known to exist as at least 3 different genotypic clades (Walker et al. 2001, P. J. Walker pers. comm.). The original YHV clade was 
described from Thailand and differs from gill-associated virus (GAV) clade of Australia by approximately $15 \%$ in nucleic acid sequence (Cowley et al. 1999). A third intermediate clade has been found in Thailand and Vietnam (P. J. Walker pers. comm.). These viruses have been included in a YHV-complex (Walker et al. 2001).

Initial diagnosis of YHV infection relied exclusively on subjective histology (Chantanachookin et al. 1993), and preliminary DNA-based techniques did not distinguish strains in the complex (Wongteerasupaya et al. 1997, Tang et al. 2002) until the recent introduction of a commercial diagnostic kit (Farming Intelligene Technology). This comprises a nested RT-PCR assay that yields different PCR amplicons for GAV and YHV. An ideal detection method would be able to distinguish all the genotypes in the complex unambiguously.

Immunological techniques can also be used to distinguish amongst viral strains. Three monoclonal antibodies against YHV were produced in Thailand (Sithigorngul et al. 2000, 2002) to assist in histopathological diagnosis of YHV and in the development of rapid tests for field use. Based on YHV structural protein designations of Nadala et al. (1997), the antigenic target of MAb V-3-2B was the $135 \mathrm{kDa}$ envelope protein, that of MAb Y-18 was the $67 \mathrm{kDa}$ capsid protein, and of MAb Y-19 it was the $22 \mathrm{kDa}$ matrix protein (Sithigornkul et al. 2000, 2002). However, more recent data have shown that V-3-2B and Y-18 target envelope proteins of $116 \mathrm{kDa}$ (gp116) and $64 \mathrm{kDa}$ (gp64), respectively, and that Y-19 targets a $20 \mathrm{kDa}$ putative nucleoprotein p20 (Jitrapakdee et al. 2003). Here, we report the use of these MAbs to study Australian and Thai shrimp specimens infected with GAV and YHV, respectively, and shrimp specimens from India and Ecuador purported by histopathology to be infected with YHV. In situ DNA hybridization was used to confirm the presence of YHV in the samples tested.

\section{MATERIALS AND METHODS}

Naturally infected shrimp. Paraffin blocks and preserved RNA samples of 2 broodstock specimens from the Andaman Sea in southern Thailand were kindly provided by Khun Supak Loa-arun and Prof. Boosirm Withayachamnarkul. Others were obtained from outbreak farms at Woongoolbar, Queensland (8 samples) and Wollongbar, New South Wales (9 samples), Australia, the latter with the kind assistance of Dr. R. B. Callinan. Paraffin blocks from Ecuador (8 samples) and India (10 samples) were kindly provided by Dr. Victoria Alday de Graindorge and Dr. Madavi Roccam, respectively.
Source of YHV for experimental infections. Moribund Penaeus monodon were obtained in 1999 from a Thai commercial shrimp pond experiencing a YHV disease outbreak that was confirmed by histology (Chantanachookin et al. 1993) and RT-PCR using the IQ2000 detection kit (Farming Intelligene Technology). Hemolymph was withdrawn from the ventral abdominal sinus into syringes containing an equal volume of shrimp salt solution (SSS, $450 \mathrm{mM} \mathrm{NaCl}, 10 \mathrm{mM} \mathrm{KCl}$, $10 \mathrm{mM}$ ethylenediamine-tetra-acetic acid [EDTA], $10 \mathrm{mM}$ N-[2-hydroxyethyl] piperazine-N'-2-ethanesulfonic acid [HEPES]). This crude preparation of pathogenic YHV was aliqoted and stored at $-80^{\circ} \mathrm{C}$ for use as an inoculum for experimental infections.

Experimental YHV infections. Juvenile shrimp (30 Penaeus monodon, approximately $17 \mathrm{~g}$ each) were purchased from a Thai shrimp provider. They were acclimated in aerated aquaria at room temperature $\left(28\right.$ to $30^{\circ} \mathrm{C}$ ) and fed with commercial feed for $1 \mathrm{wk}$ before 15 individuals were given intramuscular injections with $0.1 \mathrm{ml}$ of the YHV inoculum diluted (1:100) in SSS. Control shrimp (15) were injected with SSS only. At $48 \mathrm{~h}$ post-injection, the shrimp were anesthetized on ice and hemolymph was withdrawn into an equal volume of $10 \%$ sodium citrate solution. This was kept on ice for virus purification as described below. One lobe of the lymphoid organ (LO) was excised from each shrimp and fixed in $4 \%$ paraformaldehyde and $0.5 \%$ glutaraldehyde in $0.1 \mathrm{M}$ cacodylate buffer, $\mathrm{pH} 7.4$, for $1.5 \mathrm{~h}$ at $4^{\circ} \mathrm{C}$, before dehydration in an ethanol series, and infiltration and embedding using the water-miscible resin LR-White (London Resin Company) for electron microscopy. The left half of each shrimp specimen was fixed with Davidson's fixative and embedded in paraffin for tissue sectioning (6 $\mu \mathrm{m}$ thickness) as previously described in Bell \& Lightner (1988).

Semi-purified YHV. The hemolymph-citrate solution from experimentally YHV-infected shrimp was diluted (1:1) in TNE buffer (0.02 M Tris-HCl, $0.4 \mathrm{M} \mathrm{NaCl}$, $0.02 \mathrm{M}$ EDTA, $\mathrm{pH}$ 7.4) and centrifuged for $30 \mathrm{~min}$ at $3000 \times g$ and $4^{\circ} \mathrm{C}$. The supernatants obtained were ultracentrifuged at $100000 \times g$ for $90 \mathrm{~min}$ at $4^{\circ} \mathrm{C}$ before the pellets were resuspended and washed twice with TNE by similar ultracentrifugation. Pellets containing YHV were resuspended in $15 \%$ sucrose $(\mathrm{w} / \mathrm{v})$ and layered onto $15 \%$ sucrose $(\mathrm{w} / \mathrm{v})$ for further ultracentrifugation as above. Finally, the pellets were combined and washed twice with TNE by ultracentrifugation as above before resuspension in a small volume of TNE and storage at $-70^{\circ} \mathrm{C}$.

Antibodies against YHV. Monoclonal antibodies were provided by P. Sithigorngul as culture fluids of mouse hybridoma clones. Clone V-3-2B was specific for gp116, Y-18 for gp64, and Y-19 for p20 of patho- 
genic YHV from Thailand (Sithigorngul et al. 2000, 2002, Jitrapakdee et al. 2003).

Immunogold labeling for electron microscopy. Immunogold labeling of ultrathin sections and semipurified virus was carried out according to methods previously described in Hyatt (1991). Anti-mouse immunogold complexes were purchased from Amersham (Auroprobes). Antibodies were diluted 1:2, 1:4 and 1:8 for screening. After treatment with antibody, the grids holding ultrathin sections were dried and stained with uranyl acetate and lead citrate while those holding whole virions were stained with $2 \%$ phosphotungstic acid for 1.5 to 3 min. Grids were examined with a Philips CM120 or a Hitachi H7000 transmission electron microscope at $100 \mathrm{kV}$.

Immunohistochemistry for light microscopy. Indirect immunoperoxidase staining using the 3 monoclonal antibodies was carried out as previously described (Sithigorngul et al. 2000). After counterstaining with haematoxylin and eosin (H\&E), the preparations were dehydrated and mounted in Permount for light microscopy.

DNA in situ hybridization. A DIG-labeled DNA probe was prepared by PCR using a plasmid containing a cDNA of the open reading frame (ORF) $1 \mathrm{~b}$ region of the YHV genome as the template (Sittidilokratna et al. 2002), with primers GY1 (5'-GAC ATC ACT CCA GA-3') and GY4 (5'-GTG AAG TCC ATG TGT GTG AGA CG-3') to amplify a 794 bp DNA fragment. Labelling was carried out using DIG-II-dUDP (Roche Molecular Biochemicals) according to instructions in the product manual (Anonymous 1996). The DIGlabeled probe was purified using a QIAquick PCR purification kit (QIAGEN) and stored in $100 \mu \mathrm{l}$ of elution buffer at $-20^{\circ} \mathrm{C}$ until used. In situ hybridization was performed according to Tang et al. (2002), except that the stringency of washing was $2 \times \operatorname{SSC}(0.3 \mathrm{M}$ $\mathrm{NaCl}, 0.03 \mathrm{M}$ sodium citrate) at room temperature for $15 \mathrm{~min}, 1 \times \mathrm{SSC}$ at $42^{\circ} \mathrm{C}$ for $15 \mathrm{~min}$, and $0.5 \times \mathrm{SSC}$ at $52^{\circ} \mathrm{C}$ for $15 \mathrm{~min}$.

RNA extraction and RT-PCR. RNA from LO samples of YHV-injected shrimp and broodstock were extracted using a NucleoSpin RNA II extraction kit (Macherey-Nagel), and RT-PCR was carried out using the $\mathrm{IQ}^{2000^{\mathrm{TM}}}$ YHV/GAV detection and typing system according to the kit instructions (Farming Intelligene Technology). PCR products were examined by electrophoresis in $1.5 \%$ agarose gels. This kit gives a common amplicon of $777 \mathrm{bp}$ for heavy infections of both GAV and YHV, but also differential amplicons of $406 \mathrm{bp}$ diagnostic for GAV infection and $277 \mathrm{bp}$ diagnostic for YHV infection. In very severe infections, an additional band may be seen at approximately 1000 bp for both YHV and GAV. The kit also produces a $680 \mathrm{bp}$ control amplicon from the shrimp $\beta$-actin gene for YHV-/GAV-negative shrimp samples. This control band does not appear in YHV-/GAV-positive samples.

Cloning and sequencing of PCR amplicons. PCR amplicons of putative GAV from 2 captured Thai broodstock ( $400 \mathrm{bp})$ were cut from electrophoresis gels and extracted using a QIAquick ${ }^{\circledR}$ gel extraction kit (Qiagen). They were inserted into the pDrive cloning vector to transform competent Escherichia coli M15 cells using a Qiagen' $\mathrm{PCR}^{\circledR}$ cloning kit. Plasmid DNA containing insert was extracted using a NucleoSpin ${ }^{\circledR}$ plasmid extraction kit (Macherey-Nagel). Both DNA strands of the inserts in 2 putative GAV clones were sequenced using M13 forward and reverse primers, Thermo-Sequenase $^{\mathrm{TM}}$ (Amersham), and automated ABI Model 377 sequencing systems (Applied Biosystems) at the Bioservice Unit, National Science and Technology Development Agency (NSTDA), Bangkok, Thailand. The DNA sequences obtained were compared to GenBank sequences for YHV (GenBank AY052786) and GAV (GenBank AF227196) using Clustal W, at www.ebi.ac.uk/embl/.

\section{RESULTS AND DISCUSSION}

\section{Immunogold labeling}

In ultrathin sections, MAb Y-19 reacted with both nucleocapsids and enveloped virions, but it did not react with intact virions in negatively stained preparations (Fig. 1). By contrast, MAb V-3-2B did not react with virus in the ultra-thin sections but did react in negatively stained preparations (Fig. 2). MAb Y-18 did not react with YHV in either type of preparation. The results (Table 1) were consistent with the specificity of $\mathrm{V}-3-2 \mathrm{~B}$ to the envelope spike protein gp116 and the specificity of MAb Y-19 to a putative nucleoprotein p20 (Sithigorngul et al. 2002, Jitrapakdee et al. 2003). Since MAb Y-18 was specific to envelope protein gp64 (Sithigorngul et al. 2002, Jitrapakdee et al. 2003), it was expected to react similarly to MAb V-3-2B. The failure of Y-18 to react with these preparations may have been due to a conformational change in gp64 caused by the fixation or staining process.

\section{Immunohistochemistry}

Using the 3 MAbs with 15 samples of our experimentally YHV-infected shrimp, similar positive immunochemical reactions (Sithigornkul et al. 2002) were observed in all YHV target tissues (Chantanachookin et al. 1993, Soowannayan et al. 2002). No reactions occurred with the control shrimp. When used with 17 samples of GAV-infected shrimp from both sites in Australia, posi- 

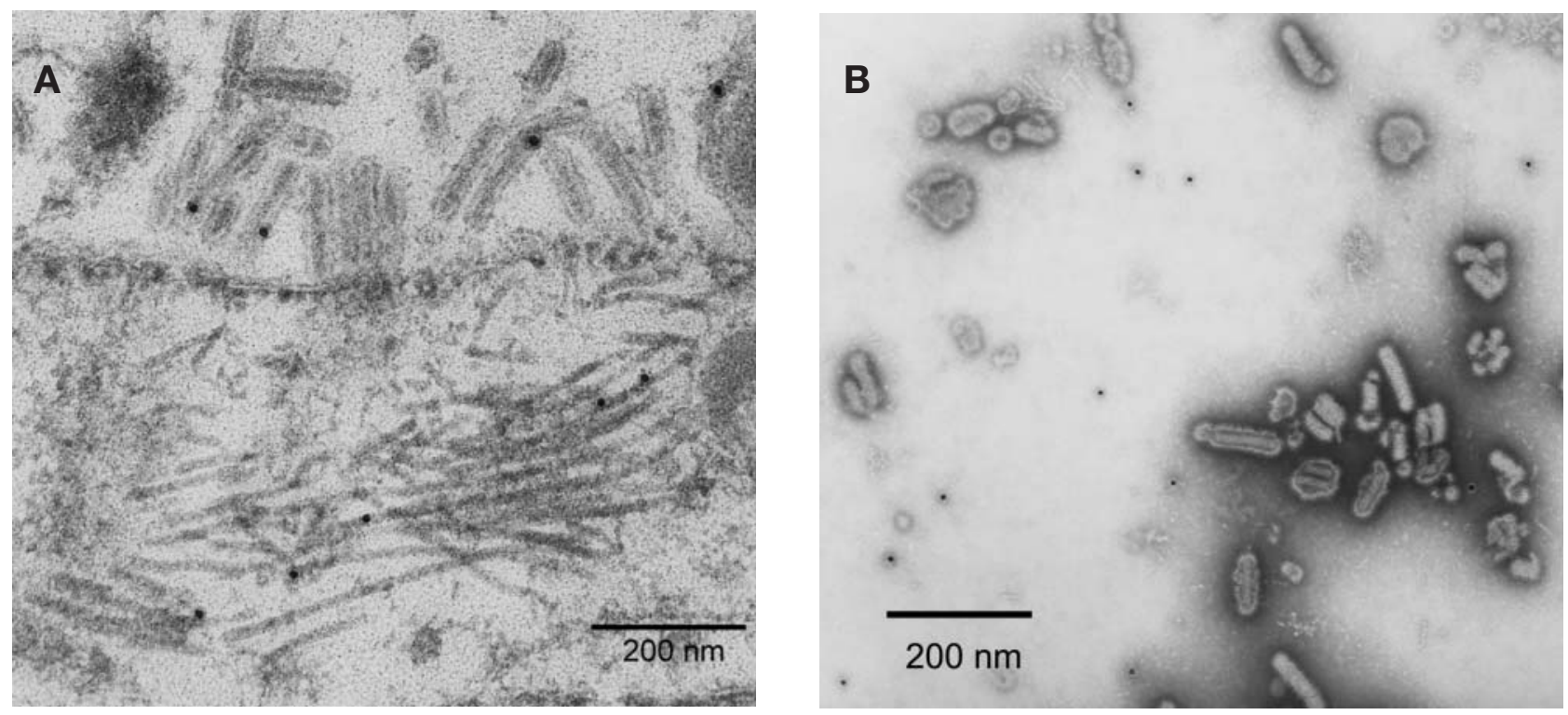

Fig. 1. Penaeus monodon. Immunogold labeling of thin sections of YHV-infected lymphoid organ (LO) and purified yellow head virus (YHV) virions using monoclonal antibody clone Y-19 (against p20 nucleoprotein). The antibody reacts with both enveloped virions and nucleocapsids in the tissue sections (A) but not with semi-purified whole virions (B). Size of the gold particles is $10 \mathrm{~nm}$

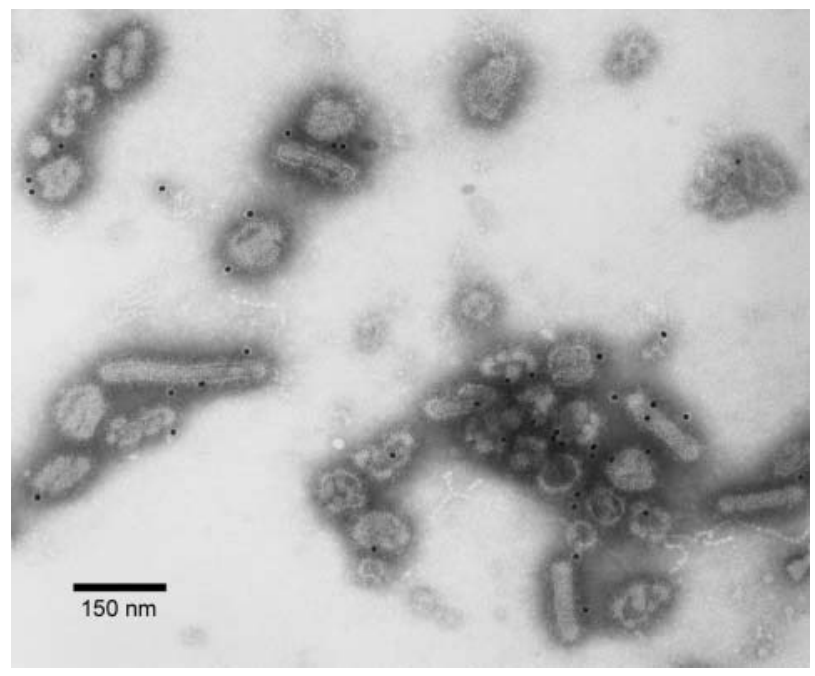

Fig. 2. Penaeus monodon. Negative contrast immunogold labeling of semi-purified yellow head virus (YHV) using monoclonal antibody (MAb) V-3-2B (against gp116 envelope glycoprotein). The antibody reacted with the enveloped virions. Size of the gold particles is $10 \mathrm{~nm}$

tive reactions were obtained with MAbs Y-18 and Y-19, but not with V-3-2B (Fig. 3) in target tissues of ectodermal and mesodermal origin (i.e. gills, LO, interstitial cells of the hepatopancreas, heart, hemocytes, vas deferens, antennal gland, connective tissues, etc.). The 2 healthy, captured broodstock specimens from southern Thailand also only reacted with MAb Y-18 and Y-19, but the reactions were confined to LO spheroids (LOS) only, and appeared identical to those shown in Fig. 3 for the Australian specimens. There was also some minor variation in the strength of $\mathrm{Y}-18$ and $\mathrm{Y}-19$ reactions that was dependent on sample type. For the GAV samples and captured Thai broodstock, strong positive reactions were observed in LOS but not in functional tubules (reaction identical to that shown in Fig. 3). By contrast, experimentally YHV-infected samples gave strong positive reactions in functional tubules and in newly formed LOS, but generally not in older LOS (Fig. 4). Strong positive reactions were also observed in peripheral nerve tissues and the eye of Woolongbar GAV-infected shrimp (see illustrations in Callinan et al. 2003) but not in YHVinfected shrimp. There were very light positive reactions in hematopoietic tissue of GAV-infected shrimp, but strong reactions in YHV-infected shrimp. No positive reactions were obtained with any of the MAb for shrimp samples with purported YHV infections from Ecuador and India (Fig. 5).

Based on reaction profile, tissue distribution and staining intensity, the $3 \mathrm{MAb}$ derived from pathogenic YHV (Sithigornkul et al. 2002) could be used to differentiate between YHV, GAV and a new GAV-like virus from 2 captured Thai broodstock. The fact that MAb V-3-2B reacts only with YHV and not with GAV supports an earlier report (Cowley et al. 1999) that YHV and GAV are distinct, although closely related, viruses.

The differences in intensity of MAb Y-18 and Y-19 reactions for various tissues in GAV and YHV infected shrimp suggested either that the hosts responded to the 2 genotypes in a slightly different manner, or that the 
Table 1. Penaeus monodon. Summary of immunogold-labeled monoclonal antibody (MAb) reactions with yellow head virus (YHV) by TEM of thin tissue sections of infected shrimp and with whole, negatively stained virions

\begin{tabular}{|c|c|c|c|c|c|}
\hline MAb & $\begin{array}{l}\text { Target size } \\
\text { (kDa) }\end{array}$ & $\begin{array}{l}\text { Protein } \\
\text { specificity }\end{array}$ & $\begin{array}{l}\text { Labeling intensity } \\
\text { in sections }\end{array}$ & $\begin{array}{l}\text { Labeling intensity } \\
\text { for whole virions }\end{array}$ & Remarks \\
\hline Y-19 & 20 & $\begin{array}{c}\text { p20 } \\
\text { nucleoprotein }\end{array}$ & ++ & + & $\begin{array}{l}\text { Specific to } \\
\text { interior }\end{array}$ \\
\hline V-3-2B & 116 & $\begin{array}{c}\text { gp116 } \\
\text { glycoprotein }\end{array}$ & - & +++ & $\begin{array}{l}\text { Specific to } \\
\text { envelope }\end{array}$ \\
\hline Y-18 & 64 & $\begin{array}{c}\text { gp64 } \\
\text { glycoprotein }\end{array}$ & - & - & $\begin{array}{c}\text { No labeling } \\
\text { observed }\end{array}$ \\
\hline
\end{tabular}
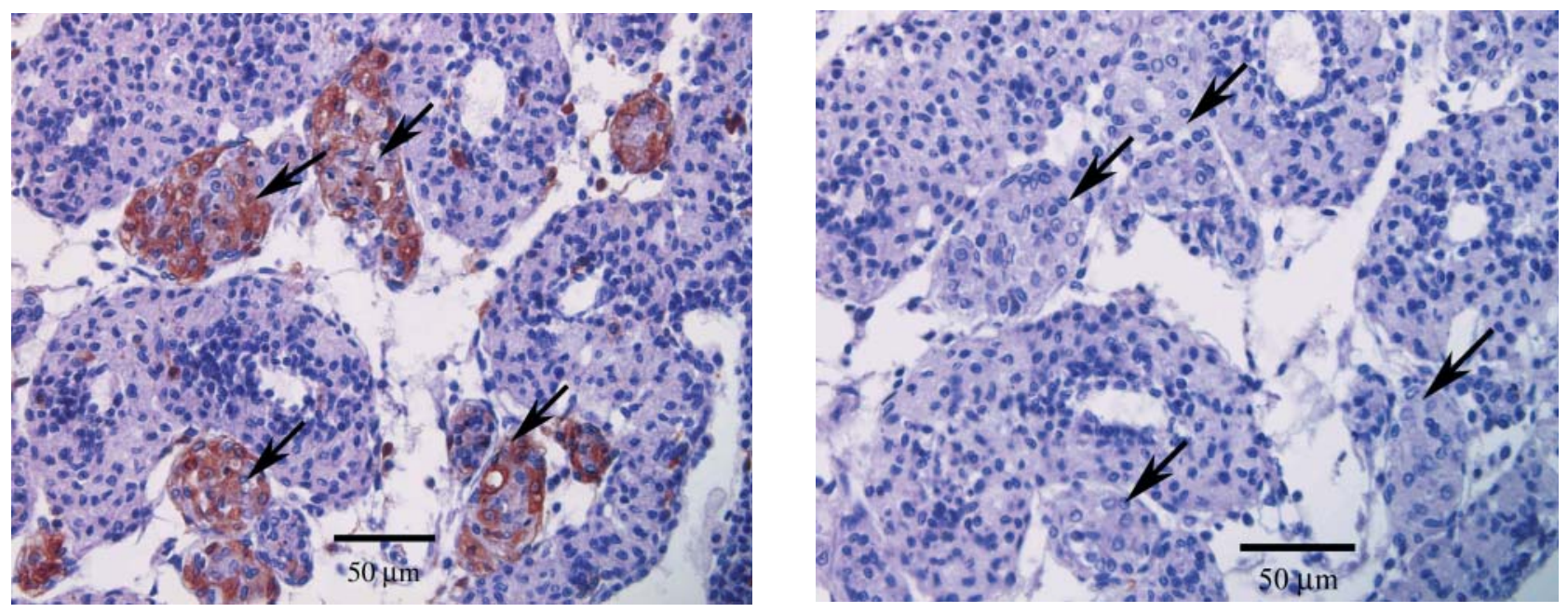

Fig. 3. Penaeus monodon. Immuno-stained gill-associated virus (GAV)-infected lymphoid organ (LO) tissue, showing strong positive reactions (brown) in LO spheroids (LOS) (arrows) using monoclonal antibody (MAb) Y-19 (A), but not with MAb V-3-2B (B), in an adjacent tissue section

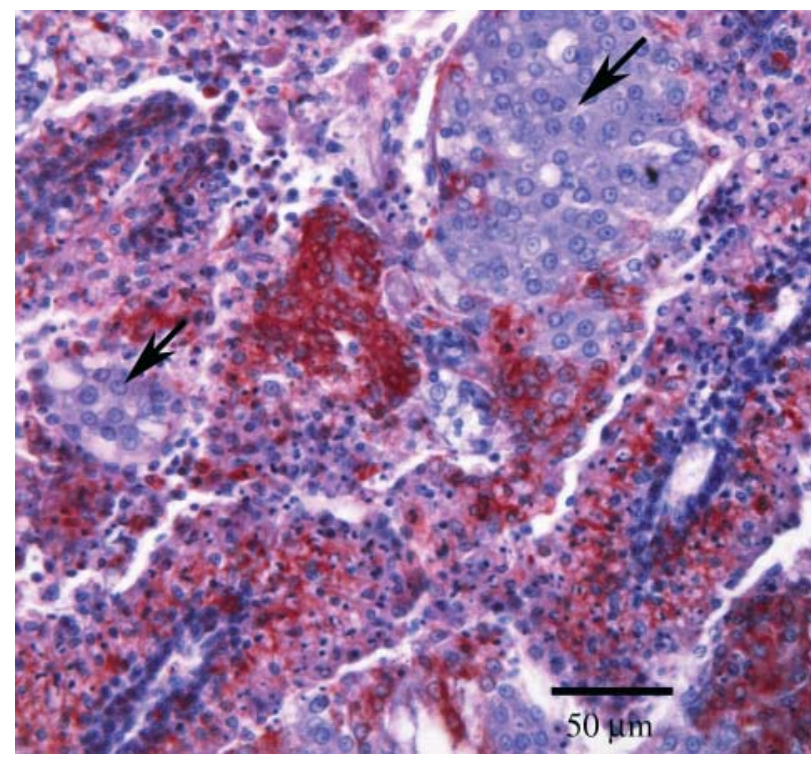

Fig. 4. Penaeus monodon. Immuno-stained lymphoid organ (LO) tissue of experimentally yellow head virus (YHV)infected shrimp showing strong positive reactions (brown) in functional tubules and weaker reactions in LO spheroids (LOS) (arrows) using monoclonal antibody (MAb) V-3-2B shrimp were at different stages of infection. A difference of the tissue distribution of GAV has recently been reported to occur during chronic and acute phases of infection (Spann et al. 2003). On the other hand, it is known that $P$. monodon in Thailand and Australia differ genetically (Benzie et al. 1993, Klinbunga et al. 1998), and that would further complicate interpretation of the results. Thai and Australian shrimp should be challenged with isolates of each virus to resolve this difficulty.

\section{In situ hybridization}

Positive DNA hybridization reactions were observed in various tissues of all the GAV, YHV and captured Thai broodstock specimens that gave positive reactions with any of the 3 MAbs (example in Fig. 6). Tissues giving positive DNA hybridization reactions corresponded to those that gave positive reactions with the MAbs, including the LO, and especially LOS, the antennal gland, antennal nerve roots, cuticular epithelial cells, etc. Some ectopic spheroids also reacted strongly with the probe (Fig. 6). The ability of the YHV 

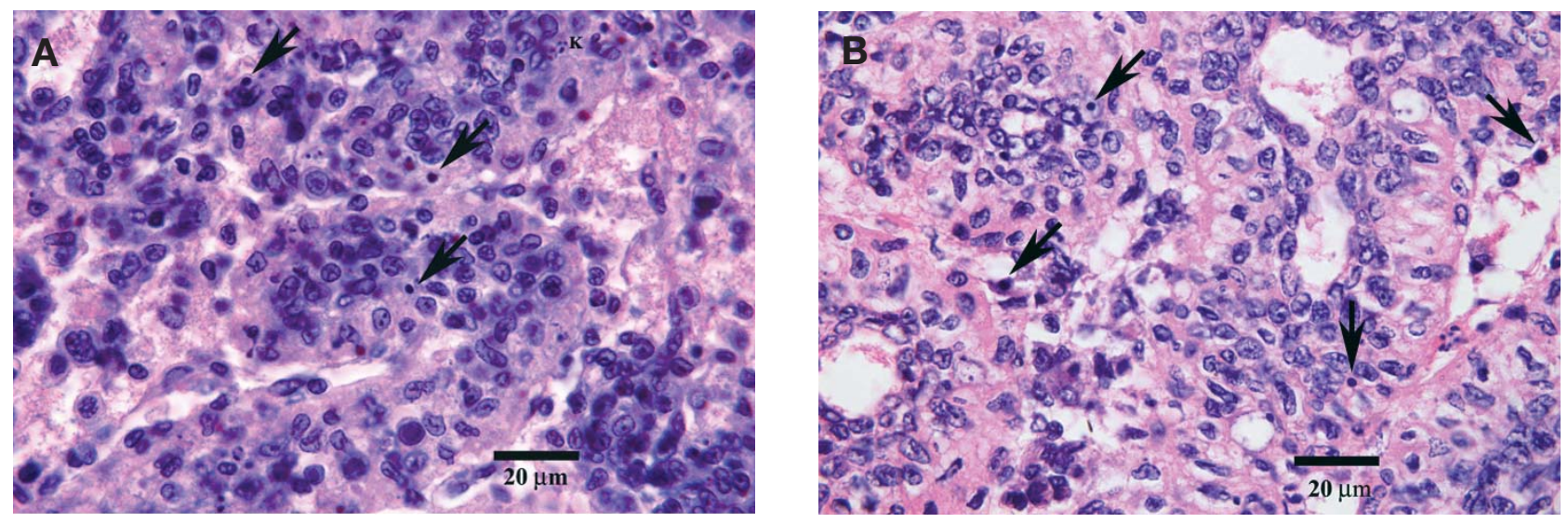

Fig. 5. Penaeus monodon. Immuno-staining (Y-19) of lymphoid organ (LO) tissue of shrimp from (A) India (Penaeus monodon) and (B) Ecuador (P. vanamei). Both show pyknotic and karyorrhectic nuclei (arrows) typical of yellow head virus (YHV) infections, but no immunoreaction
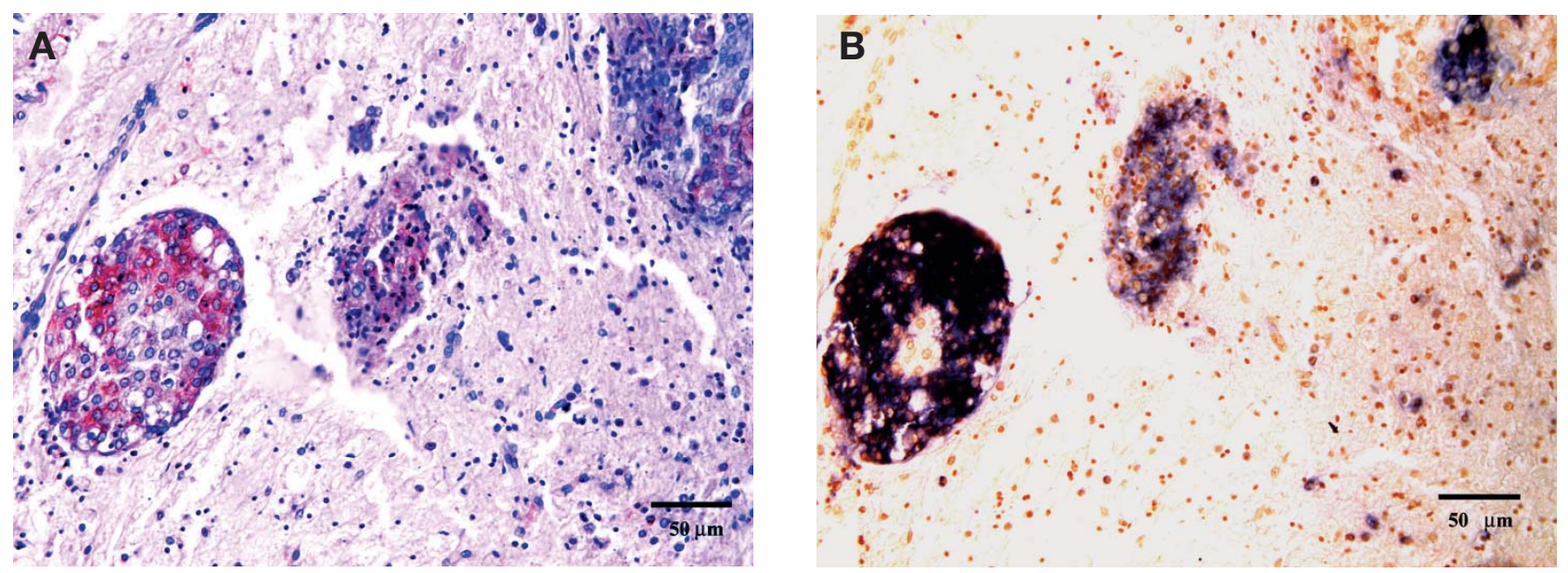

Fig. 6. Penaeus monodon. Immuno-staining (V-3-2B) and in situ DNA hybridization with yellow head virus (YHV)-infected shrimp tissue showing strong positive immunochemical (brown, A) and in situ hybridization (dark blue, B) reactions in ectopic spheroids (in connective tissue near the pereiopods)

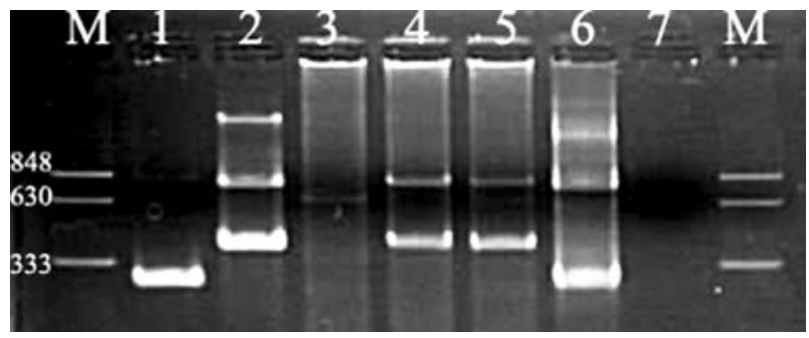

Fig. 7. Detection of RT-PCR products from yellow head complex viruses. Lanes: $\mathrm{M}=$ marker, 1 = YHV kit positive control, 2 = gill-associated virus (GAV) kit positive control, 3 = uninfected shrimp, $4 \& 5=$ Thai broodstock samples, $6=$ yellow head virus (YHV) -injected shrimp, $7=$ Negative control. Uninfected shrimp (Lane 3) show a shrimp-specific band at $680 \mathrm{bp}$. The GHV positive kit control (Lane 2) and YHV experimentally infected shrimp (Lane 6) each give 3 bands, indicating very high levels of target template
DNA probe to hybridize GAV, despite $15 \%$ divergence in overall RNA sequence, has already been reported (Tang et al. 2002a), and it shows that PCR or MAb are the only current detection techniques that can reveal YHV genotype differences.

Most of the severe focal lesions seen in peripheral nerves and central nerves of GAV-infected specimens reacted only lightly or moderately with the DNA probe when compared to reactions in LO tissue of the same specimens, or in YHV-infected tissues generally. This could mean that the distribution of GAV was less uniform and more concentrated in the LO than in other tissues. These results were similar to those with the crossreacting MAbs Y-18 and Y-19, and may be related to genetic differences in the viruses, hosts, or to the stage of infection as discussed above. 
BYHV GACATCACTCCAGACAACATCTGTCCAGAGGGTGTCTATGACTTCGAGACCTTTAGGATC 60

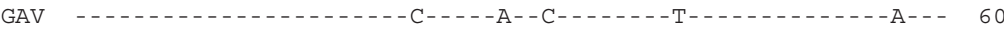

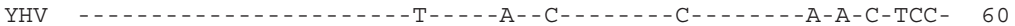
BYHV GGCACTTGCGACCCCATCAAAGCGCTAAACGCTGTCTTCTACTGTATCGAACGACACTGG 120

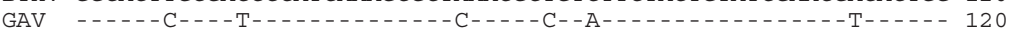

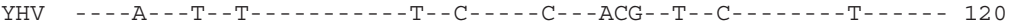

BYHV TTCTCTTCTGGCCTCTCCATCTCCTGCGCATCCATCTACCCACACGCAAACATGACAATT 180

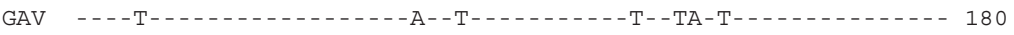

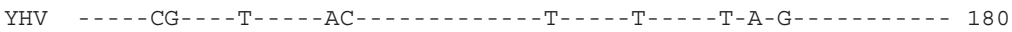

BYHV CATCAATACAAGGAGGCATTCAACCTTTACACCAATGAACTTGCCACAGAGGTCACACTT 240

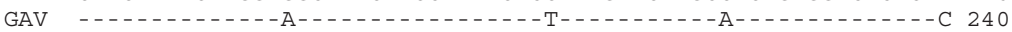
YHV -----G----A--A-----GCA--C----T-CA---T-GAA-----A----T--C 240

BYHV AAACATCAGCCAACATTCGACTCCTACCTCTCATTCATGCTCACCAAGGAACGCCACAAC 300

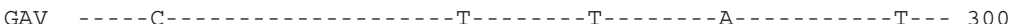

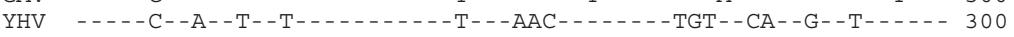

BYHV ATCAACATCGACATTGGTACAGGCGCAAACACTTTCTACACTTCCTTCGACACAATCAAC 360

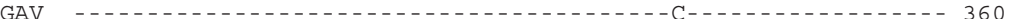

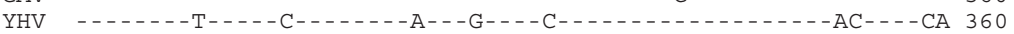

BYHV TCAGCTCCATGCACAGACGAACGCTACGAGGAAGTCATGATAGGTGTCACTCGTCTCTAC 420

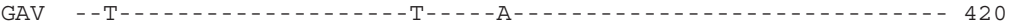

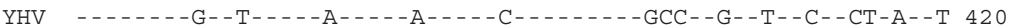

BYHV TAC 423

GAV - - 423

YHV $\quad-$ - T 423

Fig. 8. Comparison of the PCR amplicon sequence from captured Thai broodstock (BYHV) with those for gill-associated virus (GAV) (GenBank AF227196, positions 12808 to 13231) and yellow head virus (YHV) (GenBank AY052786, positions 828-1251) using Clustal W. Blanks, indicating bases identical to those in the BYHV sequence

No positive hybridization reactions were observed in purportedly YHV-infected tissues of shrimp samples from Ecuador or India. Since tentative diagnosis of YHV in these specimens was based entirely on histopatholgy by H\&E staining (Fig. 5), it can be concluded only that the tissues do not react with either the 3 MAbs tested or the in situ hybridization probe. Confirmation of YHV infections in these shrimp would require further information, ideally provided by transmission electron microscopy (TEM). If these specimens were indeed infected with YHV complex viruses, our results suggest that they are quite distant from GAV and Thai YHV.

\section{RT-PCR and sequence analysis}

Immunohistochemical reactions of 2 Thai captured broodstock were similar to those of GAV, and RT-PCR also generated amplicons ( 406 bp) that were diagnostic for GAV (Fig. 7) rather than amplicons (277 bp) diagnostic for YHV. Cloning and sequence analysis of the amplicons from these 2 broodstock revealed that they were $423 \mathrm{bp}$ in length, and identical in sequence. They shared $92.7 \%$ identity to a comparable region of the reported sequence for GAV, but only $79.0 \%$ identity to that of YHV (Fig. 8).

The sequence information placed the amplicons from the 2 broodstock closer to GAV than to YHV, and this corresponds to results from an earlier report of a second YHV complex virus in Thailand (Walker et al. 2001). It is currently possible to distinguish between YHV and the second genotype in Thailand using MAb-3-2B or the IQ2000 RTPCR method, but GAV cannot be distinguished from the second YHV genotype. Captured broodstock are known to be sourced over a wide geographical area and it is possible that GAV may eventually be introduced into Thailand because of this practice. Thus, an improved RTPCR method should be devised.

This work supports earlier reports that there are at least 3 genotypes in the yellow head virus complex (Walker et al. 2001). We have shown that MAb 3-2B against envelope protein gp116 can differentiate between YHV and either GAV or the new Thai YHV genotype, while MAbs Y-18 and Y-19 cross-react. Thus, the capability of immunohistochemistry with these MAbs to distinguish among genotypes is similar to that of current RT-PCR methods. In contrast, in situ hybridization is less discriminatory, giving positive reactions for all. It is possible that MAb to other gp116 epitopes, or modification of current RT-PCR methods, would allow for improved discrimination of genotypes.

Acknowledgements. The authors would like to thank the Australian Center for International Agricultural Research and the Thai National Center for Genetic Engineering and Biotechnology for supporting this research. The authors are also indebted to Drs. V. Alday de Graindorge and M. Roccam for providing shrimp specimens from Ecuador and India, respectively.

\section{LITERATURE CITED}

Anonymous (1996) Nonradioactive in situ hybridization application manual, 2nd edn. Roche Molecular Biochemicals, Mannheim

Bell TA, Lightner DV (1988) A handbook of normal shrimp histology. World Aquaculture Society, Baton Rouge, LA

Benzie JAH, Ballment E, Frusher S (1993) Genetic structure of Penaeus monodon in Australia: concordant results from mtDNA and allozymes. Aquaculture 111:89-93

Callinan RB, Jiang L, Smith PT, Soowannayan C (2003) Fatal, virus-associated peripheral neuropathy and retinopathy in farmed Penaeus monodon in eastern Australia. I. Pathology. Dis Aquat Org 53:181-193

Chantanachookin C, Boonyaratanapalin S, Kasornchandra J, Direkbusarakom S, Ekpanithanpong U, Supamataya K, Siurairatana S, Flegel TW (1993) Histology and ultrastructure reveal a new granulosis-like virus in Penaeus monodon affected by 'yellow-head' disease. Dis Aquat Org 17:145-157

Cowley JA, Dimmock CM, Wongteerasupaya C, Boonsaeng 
V, Panyim S, Walker PJ (1999) Yellow head virus from Thailand and gill-associated virus from Australia are closely related but distinct prawn viruses. Dis Aquat Org 36:153-7

Cowley JA, Dimmock CM, Spann KM, Walker PJ (2000) Gillassociated virus of Penaeus monodon prawns: an invertebrate virus with ORF1a and ORF1b genes related to arteriand coronaviruses. J Gen Virol 81:1473-84

Flegel TW (1997) Special topic review: major viral diseases of the black tiger prawn (Penaeus monodon) in Thailand. World J Microbiol Biotechnol 13:433-442

Hyatt A (1991) Immunogold labelling techniques. In: Harris R (ed) Electron microscopy in biology: a practical approach. Oxford University Press, Oxford, p 59-80

Jitrapakdee S, Unajak S, Sittidilokranta N, Hodgson RAJ, Cowley JA, Walker PJ, Panyin S, Boonsaeng V (2003) Identification and analysis of gp116 and gp64 structural glycoproteins of yellow head nidovirus of Penaeus monodon shrimp. J Gen Virol 84:863-873

Klingbunga S, Penman DJ, McAndrew BJ, Tassanakajon A, Jarayabhand P (1998) Genetic variation, population differentiation and gene flow of the giant tiger shrimp (Penaeus monodon) inferred from mtDNA-RFLP data. In: Flegel TW (ed) Advances in shrimp biotechnology. National Center for Genetic Engineering and Biotechnology, Bangkok, p 51-59

Mayo MA (2002) A summary of taxonomic changes recently approved by ICTV. Arch Virol 147:1655-1656

Nadala ECBJ, Tapay LM, Loh PC (1997) Yellow-head virus: a rhabdovirus-like pathogen of penaeid shrimp. Dis Aquat Org 31:141-146

Sithigorngul P, Chauychuwong P, Sithigorngul W, Longyant S, Chaivisuthangkura P, Menasveta P (2000) Development

Editorial responsibility: Otto Kinne (Managing Editor), Oldendorf/Luhe, Germany of a monoclonal antibody specific to yellow head virus (YHV) from Penaeus monodon. Dis Aquat Org 42:27-34

Sithigorngul P, Rukpratanporn S, Longyant S, Chaivisuthangkura P, Sithigorngul W, Menasveta P (2002) Monoclonal antibodies specific to yellow-head virus (YHV) of Penaeus monodon. Dis Aquat Org 49:71-76

Sittidilokratna N, Hodgson RAJ, Cowley JA, Jitrapakdee S, Boonsaeng V, Panyim S, Walker PJ (2002) The complete ORF1b-gene sequence indicates yellow head virus is an invertebrate nidovirus. Dis Aquat Org 50:87-93

Soowannayan C, Sithigorngul P, Flegel TW (2002) Use of a specific monoclonal antibody to determine tissue tropoism of yellow head virus (YHV) of Penaeus monodon by in situ immunocytochemistry. Fish Sci 68(Suppl 1):805-809

Spann KM, McCulloch RJ, Cowley JA, East IJ, Walker PJ (2003) Detection of gill-associated virus (GAV) by in situ hybridization during acute and chronic infections of Penaeus monodon and $P$. esculentus. Dis Aquat Org 56(1):1-10

Tang KFJ, Spann KM, Owens L, Lightner DV (2002) In situ detection of Australian gill-associated virus with a yellow head virus gene probe. Aquaculture 205:1-5

Walker PJ, Cowley JA, Spann KM, Hodgson RAJ, Hall MR, Withyachumanarnkul B (2001) Yellow head complex viruses: transmission cycles and topographical distribution in the Asia-Pacific region. In: Browdy CL, Jory DE (eds) The new wave. Proc Spec Sess Sustainable Shrimp Culture, Aquaculture 2001. World Aquaculture Society, Baton Rouge, LA, p 292-302

Wongteerasupaya C, Boonsaeng V, Panyim S, Tassanakajon, Withyachumanarnkul B, Flegel TW (1997) Detection of yellow-head virus (YHV) of Penaeus monodon by RT-PCR amplification. Dis Aquat Org 31:181-186

Submitted: December 18, 2002; Accepted: August 24, 2003 Proofs received from author(s): November 26, 2003 